\title{
Pengalaman Belajar Siswa Berdasarkan Kurikulum 2013 Pada Mata Pelajaran PPKn di MTsN 2 Rokan Hulu
}

\author{
Adilla Fitri, Hasrul \\ Prodi Pendidikan Pancasila dan Kewarganegaraan \\ FIS Universitas Negeri Padang \\ E-mail: hasrulpiliang@fis.unp.ac.id
}

\section{ABSTRAK}

Penelitian ini bertujuan untuk mengetahui pengalaman belajar siswa berdasarkan kurikulum 2013 pada mata pelajaran PPKn di MTS Negeri 2 Rokan Hulu. Pengalaman belajar siswa berdasarkan kurikulum 2013 dilihat dari kegiatan belajar siswa yaitu melalui pendekatan saintific approach, atau kegiatan 5 M yaitu mengamati, menanya, mengumpulkan data, mengolah data dan mengkomunikasikan yang berpusat pada siswa. Metode yang digunakan dalam penelitian ini adalah mixed method dengan model sequential eksplanator (urutan Pembuktian). Informan dalam penelitian ini sebanyak 88 responden untuk mendapatkan hasil angket dan 13 informan yang dipilih melalui purposive sampling. Teknik pengumpulan data berupa angket, wawancara dan dokumentasi. Uji keabsahan data terdiri dari kuantitatif dengan menggunakan validitas dan realibilitas sedangkan uji keabsahan data kualitatif menggunakan metode triangulasi sumber. Hasil penelitian mengungkapkan bahwa pengalaman belajar siswa berdasarkan kurikulum 2013 dalam pembelajaran PPKn melalui kegiatan saintiffic Approach (5M) sudah dilaksanakan dan respon siswa terhadap kegiatan 5M yang bermacam-macam seperti ada yang yang aktif, kreatif dan pasif dengan memadukan model pembelajaran discovery learning, $P B L$, dan cooperatif learning serta menggunakan menggunakan fasilitas dan sumber belajar untuk menunjang pembelajaran siswa pada mata pelajaran PPKn di MTsN Rokan Hulu.

Kata Kunci: Pengalaman Belajar, Kurikulum 2013, Mata pelajaran PPKn

\section{ABSTRACT}

This research aims to knowing the learning experince of students from curriculum of 2013 in subject civic education Islamic Junior High State School 2 Rokan Hulu. The study learning experience of students based on curriculum 2013 seen by how students do from saintiffic approach or " $5 M$ " there are monitoring, asking, collecting data, processing, and communicate to the students. The method used by this research is mixed method with model sequential explenator. for informant needed as many 88 of respondents to get the research of questionnaire and 13 of informants has choosen by purposive sampling. The techniques data colled by questionnaire, interview and documentation. Exmination validity data technique is using from method quatitative is using validation and rehabilitation if the validity of data such qualitative using triangulation source method. The result of this research students study by curriculum of 2013 in on civic education by saintiffic approach (5M) have finished and many kinds of students responses such as active, creative and passive and combined 
discovery learning method, PBL, cooperatif learning conventional method it's speech, also fasility and source of learning to support study of students in civic education Islamic Junior High State School 2 Rokan Hulu.

Keywords: leraning experience, cuririculum of 2013, civic education

(c) (i) (2) This work is licensed under the Creative Commons Attribution-ShareAlike 4.0 International License. EY SA 02020 by author.

\section{PENDAHULUAN}

Proses pembelajaran yang dilakukan peserta didik akan memberikan pengalaman yang akan mengembangkan wawasan atau pengetahuan serta membuahkan perubahan perilaku dari aspek pengetahuan, sikap dan keterampilan. Pengalaman belajar yaitu beberapa aktivitas peserta didik yang dilakukan untuk mendapatkan informasi dan kompetensi baru sesuai dengan tujuan yang akan dicapai. Dalam kegiatan belajar dan pembelajaran tidak akan terlepas dari pengetahuan dasar dan pengalaman yang telah dimiliki peserta didik dari pengalaman yang telah didiapatkan mempermudah peserta didik untuk memahami pelajaran yang akan dipelajari (wina 2012:160). Pada tahun 2013 pemerintah memperbaiki sistem pendidikan dengan memberlakukan kurikulum baru yaitu kurikulum 2013 yang menggantikan kurikulum KTSP. Menurut fadlilah (2014:16) kurikulum 2013 merupakan seperangkat perencanaan sebagai pedoman peserta didik untuk mengembangkan kemampuan soft skills dan hard skills yang menitikberatkan kepada tiga ranah yaitu pengetahuan, sikap dan keterampilan.

Kurikulum 2013 memiliki karakteristik sebagai kurikulum yang mengembangkan keseimbangan antara pengembangan sikap, spriritual dan sosial, rasa ingin tahu, kreativitas, kerja sama dengan kemampuan intelektual dan psikomotorik. Sekolah merupakan bagian dari masyarakat yang memberikan pengalaman belajar terencana dimana peserta didik menerapkan apa yang dipelajari di sekolah ke masyarakat dan memanfaatkan masyarakat sebagai sumber belajar (permendikbud Nomor 70 Tahun 2013).

Karakteristik kurikulum 2013 yang demikian sesuai dengan tujuan umum dari Pendidikan Kewarganegaraan yang dikemukan oleh Sudrajat (2017:303) yaitu bertujuan mengembangkan potensi individu warga negara yang memiliki rasa kebangsaan dan cinta tanah air dalam konteks nilai Pancasila, kesadaran konstitusi yaitu UndangUndang Dasar 1945, semangat Bhinneka Tunggal Ika dan juga komitmen Negara Kesatuan Republik Indonesia. Pembelajaran PPKn dalam kegiatan belajar memerlukan pendidik yang berkualitas. Seorang guru harus mampu menguasai metode mengajar yang sesuai dengan kompetensi dasar agar tercapainya tujuan pembelajaran yang di harapkan guru. Dengan demikian maka seorang guru PPKn haruslah 
menjadi guru yang berkualitas dan profesional, sebab jika guru tidak berkualitas tentu tujuan PPKn itu sendiri tidak tercapai.

Pelaksanaan kurikulum 2013 pada mata pelajaran PPKn bertujuan untuk memberikan pengalaman belajar yang baik kepada peserta didik. Dengan memberikan pengalaman belajar yang dimiliki peserta didik dapat membantu sisiwa untuk mempermudah peserta didik untuk memahami pelajaran yang baru ataupun yang sulit. Seperti dengan yang dikemukan oleh Eva (2016:1533) pembelajaran PPKn dalam kurikulum 2013 guru menggunakan pendekatan pembelajaran saintific approach melalui kegiatan mengamati, menanya, mengumpulkan data, mengasosiasikan dan mengkomunikasikan(5M). Kegiatan 5M ini diharapkan akan memberikan semangat, motivasi kerativitas, berpartisispasi aktif dan kemandirian sesuai dengan kemampuan peserta didik selama proses pembelajaran berlansung.

$\begin{array}{cccr}\text { MTsN } & 2 & \text { Rokan } & \text { Hulu } \\ \text { merupakan } & \text { salah } & \text { satu } & \text { sekolah }\end{array}$ unggulan tingat menengah pertama yang ada di kabupaten Rokan Hulu. Sekolah yang berada dibawah binaan Kementerian Agama ini mampu bersaing dengan sekolah-sekolah unggulan lain di Kabupaten Rokan Hulu. MTsN 2 Rokan Hulu juga menjadi sekolah pilot project yang dirancang untuk pengujian program pemerintah baru dikabupaten Rokan Hulu. Salah satu program tersebut adalah kurikulum 2013 diberlakukan sejak tahun ajaran 2013/2014.

Berdasarkan observasi awal guru sudah menerapkan kurikulum 2013 dalam memimpin pembelajaran untuk tujuan lebih mengaktifkan siswa dalam menjalankan proses belajarnya. Namun belum semua siswa yang aktif mengikuti proses pembelajaran dan tidak serius dalam belajar melalui kegiatan $5 \mathrm{M}$. Guruguru PPKn telah memiliki pengalaman yang cukup baik dalam mengajar peserta didik agar peserta didik memiliki pengalaman yang baik dalam belajar. Proses pembelajaran yang baik dan benar dilihat dari lima aspek pengamalan yaitu: mengamati, menanya, mengumpulkan informasi, mengolah informasi dan mengkomnunikasikan yang dikenal dengan pendekatan Saintific Approach. Namun kenyataannya pengalaman belajar peserta didik belum sepenuhnya didapatkan. Hal ini karena kondisi peserta didik yang kurang aktif di kelas terlihat dari respon peserta didik yang malas mengikuti pembelajaran dan pada kegiatan bertanya serta mengkomunikasikan keberanian dalam bertanya. Sehubungan dengan hasil observasi awal dapat diketahui bahwa siswa belum sepenuhnya mendapatkan pengalaman belajar PPKn melalui perolehan nilai, siswa belum mencapai target KKM yang ditetapkan sekolah yaitu 80 sebagaimana yang diperoleh dari nilai rata -rata ulangan harian siswa kelas VIII.6 yaitu 68,2 \% yang dibawah target nilai KKM yaitu 80 di mana 58,3 $\%$ atau 20 siswa belum tuntas sedangkan siswa $44,5 \%$ atau 16 siswa sudah tuntas dalam pembelajaran PPKn.

Kegiatan pembelajaran yang diterapkan di MTsN 2 Rokan Hulu belum sesuai dengan harapan berdasarkan tujuan kurikulum 2013. Guru masih memberikan materi PPKn 
dengan metode ceramah dan kadangkadang metode diskusi kelompok diskusi sehingga kegiatan saintiffic approach yang mengutamakan keaktifan siswa belum maksimal dan pengalaman siswa dalam menjalani proses belajarnya belum mencapai target KKM sebagaimana yang diharapkan.

\section{METODE PENELITIAN}

Penelitian ini menggunakan jenis penelitian mixed method dalam model sequential eksplanator (urutan pembuktian). Menurt Creswell dalam Sugiyono (2017:404), mixed method adalah penelitian yang mengombinasikan atau mengabungkan antara metode penelitian kualitatif dan kuantitatif. Sampel dalam penelitian ini sebanyak 88 siswa dari populasi 742 siswa yang terdiri dari siswa kelas VII, VIII dan IX dengan menggunakan teknik proportionate stratified random sampling serta informan penelitian sebanyak 13 siswa yang dipilih melalui purposive sampling. Data diperoleh melalui wawancara dan dokumentasi. Uji keabsahan data terdiri dari kuantitatif dengan validitas menggunakan SPSS versi 16, batas valititas item angket dalam penelitian ini ditetapkan sebesar 0,4629 dan uji reabilitas digunakan program SPSS versi 16 dengan ketentuan koefisien Croanbach's Alpha. Batas realibilitas item angket dalam penelitian ini digunakan sebesar 0,6. Sedangkan uji keabsahan data kualitatif menggunakan metode triangulasi sumber.
HASIL DAN PEMBAHASAN

Pengalaman Belajar Siswa Berdasarkan Kurikulum 2013 pada Mata Pelajaran PPKn di MTS N 2 Rokan Hulu.

Berdasarkan olahan data angket/kusioner dan wawancara mengenai pengalaman belajar siswa berdasarkan kurikulum 2013 pada mata pelajaran PPKn di MTS Negeri 2 Rokan Hulu kepada sampel penelitian sebanyk 88 siswa terdiri dari peserta didik kelas VII, VIII dan IX dengan total populasi 742 siswa, didapatkan hasil seperti table berikut:

Tabel 1. Pengalaman Belajar Siswa Berdasarkan Kurikulum 2013 pada Mata Pelajaran PPKn di MTS Negeri 2 Rokan Hulu.

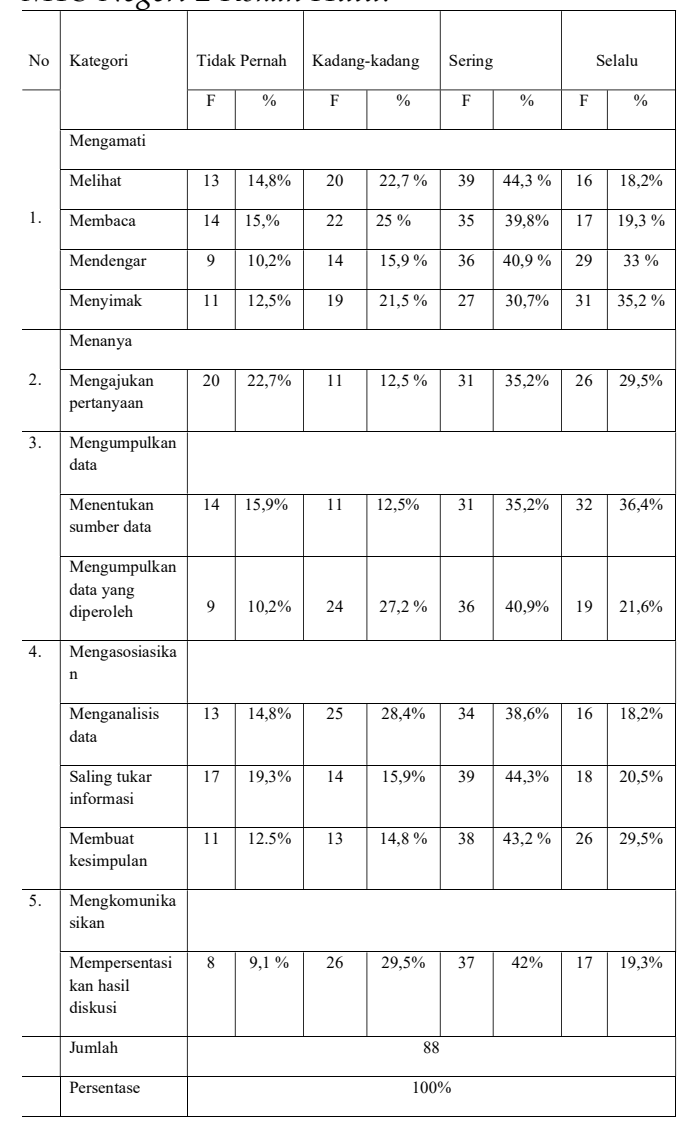


Hasil angket dan Wawancara siswa MTS Negeri 2 Rokan Hulu melalui 5 indikator tersebut dapat dijelaskan sebagai berikut:

\section{Mengamati}

Mengamati suatu materi yang diberikan guru agar peserta didik dapat menemukan fakta yang berhubungan dengan materi pelajaran melalui video, gambar dan miniatur yang disajikan oleh guru yang dikemukakan oleh Daryanto (2014:60). Kegiatan mengamati terdiri dari aspek melihat, mendengar dan membaca sebagai suatu cara untuk peserta didik menemukan fakta bahwa ada hubungan antara objek yang akan dianalisis dengan materi pembelajaran yang digunakan guru. Kegiatan membaca dalam proses pembelajaran menyatakan sering sebanyak $47 \%$ siswa membaca materi pembelajaran PPKn di LKS dan buku paket. Kegiatan ini sangat bermanfaat bagi siswa karena dapat meningkatkan pemahaman, memperluas wawasan dan memberikan ringkasan terhadap materi pembelajaran.

Hal tersebut juga membuktikan bahwa guru PPKn menggunakan media dan sumber belajar seperti buku paket dan LKS sehingga dapat dikatakan bahwa guru PPKn di MTS Negeri 2 Rokan Hulu kurang mampu menggunakan media pembelajaran yang kreatif dan inovatif hanya mengandalkan media dan sumber belajar yang sudah tersedia. Sedangkan dilihat dari kegiatan mendengarkan dan menyimak masih cukup maksimal. Ini dibuktikan dengan hasil angket menujukkan sebanyak 53\% menyatakan sering mendengarkan guru menjelaskan materi pembelajaran. Hal ini berarti sebagian siswa ada yang serius dan tidak serius ketika mendengarkan penjelasan guru. Dikarenakan faktor dari guru lebih nyaman menggunakan metode ceramah yang dominan belajar satu arah sehingga konsentrasi siswa dalam pembelajaran dapat terganggu dan siswa mendengarkan penjelasan guru disebabkan akan adanya kegiatan tanya jawab dimana siswa ingin memperoleh nilai tambahan dari siapa yang bisa menjawab pertanyaan guru.

\section{Menanya}

Kegiatan Menanya merupakan membuat dan mengajukan pertanyaan tentang informasi yang tidak dipahami dari apa yang diamati atau pertanyaan untuk mendapatkan informasi tambahan tentang apa yang diamati. Guru memberikan kesempatan siswa untuk bertanya, dimana sebanyak $49,4 \%$ yang menyatakan selalu mengajukan pertanyaan. Hal ini berarti siswa melakukan tanya jawab bersama guru PPKn. Namun, masih ada ditemukan siswa yang jarang bertanya dikarenakan ada rasa malu, takut salah, bingung mau tanya tentang apa dan tidak memahami materi yang sudah di jelaskan guru di karenakan belum terbiasanya untuk mengemukakan pertanyaan dan kurang maksimal dalam kegiatan mengamati. Hal ini perlu ditingkatkan lagi karena sangat penting dalam proses pembelajaran sebagaimana yang dikemukan oleh Hosnan (2014:50) fungsi bertanya dalam kegiatan pembelajaran adalah mendorong dan menginspirasi peserta didik untuk aktif belajar, serta mengembangkan pertanyaan dari guru dan untuk dirinya sendiri. Melalui kegiatan bertanya 
dikembangkan rasa ingin tahu siswa, pertanyaan tersebut menjadi dasar untuk mencari informasi yang lebih lanjut dan beragam sumber belajar (Daryanto 2014:64).

\section{Mengumpulkan data}

Kegiatan Mengumpulkan Data atau informasi adalah kegiatan mencari data yang dilakukan selama proses pembelajaran melalui beberapa cara yaitu menentukan sumber data dan mengumpulkan data yang diperoleh. Dengan mengumpulkan informasi dari berbagai sumber yang dilakukan melalui berbagai cara seperti eksperimen, membaca sumber lain, mengamati, wawancara bertujuan untuk menjawab suatu permasalahan yang akan dibahas oleh siswa dan guru. Kegiatan menentukan sumber belajar dengan menggunakan sumber belajar dari buku paket dan LKS sebanyak 48,2\% menyatakan sering dalam kegiatan siswa menentukan sumber belajar yang tersedia di sekolah dengan bantuan guru. Hal ini berarti proses interaksi siswa dengan berbagai macam sumber yang dapat merangsang untuk belajar dan mempercepat pemahaman dan penguasaan materi pembelajaran.

Sesuai dengan pendapat Ulfa (2017:29), sumber belajar yang biasa digunakan yaitu sumber belajar cetak. Siswa akan dapat memahami materi pelajaran dan ikut berpartisipasi dalam proses belajar. Sebab, hal-hal yang dilihat siswa akan memberikan pesan yang lebih jelas, mudah dingat, dan dipahami. Hal itulah yang menjadi manfaat menggunakan sumber belajar dalam proses belajar mengajar. Meskipun sumber belajar beragam namun kenyataannya pada siswa MTS Negeri 2 Rokan Hulu menggunakan sumber belajar cetak yaitu buku paket dan LKS.

Sedangkan mengumpulkan data yang diperoleh melalui berdiskusi bersama teman kelompok dan apabila tidak mengerti bagaimana cara mengerjakan tugas dapat ditanya kepada guru sebanyak 51,8\% menyatakan sering. Hal ini berarti siswa melakukan kegiatan diskusi dengan membagi-bagi tugas mencari jawaban dari permasalahan atau tugas kemudian hasil jawabannya disatukan dan diskusikan bersama. Hal ini sesuai dengan pendapat Daryanto (2014:69) saat kegiatan diskusi guru membimbing dan membantu siswa dalam melakukan diskusi dengan kelompok dikarenakan siswa masih belum bisa berdiskusi sendiri.

\section{Mengasosiasikan}

Kegiatan menalar/ mengasosiasikan yaitu kegiatan pembelajaran dengan mengolah informasi pembelajaran yang sudah dikumpulkan untuk memperoleh simpulan. Berdasarkan angket dan hasil wawancara pengalaman belajar siswa MTsN 2 Rokan Hulu dilihat dari kegiatan menganalisis data siswa kurang mampu menganalisis data sebanyak 26,5\%. Hal ini berarti sebagian siswa mengalami kesulitan dalam memahami materi PPKn yang cukup banyak dan menyelesaikan tugas dengan tepat waktu sedangkan waktu untuk menganalisis data membutuhkan waktu yang cukup lama. Pada kegiatan ini siswa memerlukan bimbingan guru. Sesuai dengan penelitian Maulina (2018) tentang peserta didik masih memerlukan pancingan dalam mengaitkan informasi yang didapat dengan pengetahuan yang telah mereka miliki. Padahal kegiatan 
Journal of Civic Education (ISSN: 2622-237X) Volume 4 No. 12021

menalar merupakan harus siswa, karena melalui kegiatan ini peserta didik akan dapat mengolah informasi yang dibutuhkan dalam proses belajar mengajar, dengan mengaitkan informasi satu dengan lainnya.

\section{Mengomunikasikan}

Kegiatan mengomunikasikan adalah menyampaikan hasil pengamatan berdasarkan hasil analisis lisan, tertulis ataupun menggunakan media lainnya (Daryanto,2014:80). Kegiatan ini terdiri dari sub-indikator yaitu mempersentasikan hasil tugas secara lisan dan tulisan didepan kelas. Berdasarkan penelitian sebagian siswa sebanyak $48,2 \%$ sudah sering melakukan kegiatan mengomunikasikan. Hal ini berati setelah siswa dapat menyelesaikan tugas di kelas tetapi masih ada beberpa siswa yang tidak berani tampil hal ini dipengaruhi rasa malu, ditertawakan teman, gugup dan takut tidak bisa menjawab pertanyaan ketika dalam proses persentasi hasil diskusi sehingga persentasi tidak dapat berjalan dengan lancar selanjutnya juga didukung oleh hasil wawancara ketika dalam mempersentasikan tugas didepan kelas dipengaruhi oleh waktu yang terbatas sehingga tidak semua siswa yang tampil hanya perwakilan kelompok saja dan persentasi dilanjutkan pertemuan selanjutnya.

Ketika menampilkan hasil tugasnya guru mengingatkan siswa untuk menghargai siswa sedang persentasi dengan cara memperhatikan siswa persentasi didepan kelas. Hal ini bertujuan untuk mengembangkan sikap toleransi siswa. Sementara menurut Hosnan (2014:74) melalui kegiatan mengomunikasikan, peserta didik diharapkan sudah dapat mempresentasikan hasil temuannya untuk kemudian ditampilkan di depan khalayak ramai sehingga rasa berani dan percaya diri dapat lebih terasah.

\section{KESIMPULAN}

Pengalaman belajar siswa MTsN 2 Rokan Hulu secara keseluruhan berjalan dengan baik melalui kegiatan mengamati, menanya, mengumpulkan data, mengasosiasikan dan mengomunikasikan. Namun, masih ada kendala-kendala yang dialami siswa selama belajar PPKn yaitu pada kegiatan mengamati sebagian siswa belum sepenuhnya konsentrasi dalam menyimak penjelasan guru. Hal ini dipengaruhi oleh metode pembelajaran yang digunakan guru PPKn dengan metode ceramah dan siswa lain mengaggu temannya dalam menyimak materi pembelajaran PPKn yang diberikan guru.

\section{DAFTAR PUSTAKA}

Daryanto.2014. Pendekatan

Pembelajaran Saintifik Kurikulum

2013. Yogyakarta: Gava Media.

Fadlillah, Muhammad. 2014.

Impelemntasi Kuirkulum 2013

Dalam Pembelajaran SD/MI, SMP/MTS,

SMA/MA.Yogjakarta: Ar-Ruzz

Media

Hosnan, M. 2014.Pendekatan Saintifik

dan Kontekstual dalam

Pembelajaran Abad 21 Kunci

Sukses Implementasi Kurikulum

2013. Jakarta: GhaliaIndonesia.

Maulina, Putri Hendria, dkk. 2018.5M (Mengamati, Menanya, Mencoba, Menalar danMengkomunikasikan) Tema Cita-Citaku Kelas IvSd Negeri 157 
80 | pengalaman belajar..

Palembang). Jurnal Inovasi Sekolah Dasar, Vol.5, No.2, 2018

Sanjaya,Wina $2012 \quad$.Strategi Pembelajaran Berorientasi Standar Proses Pendidikan. Jakarta: PT Kencana Prenada Media

Sudrajat, Ajat. 2017. Peranan guru PPKn dalam Penilaian Pembelajaran Sesuai Kurikulum 2013 di SMK Ma arifat Wates Kab.
Kulon Progo.Jurnal Pendidikan Kewarganegaraan dan Hukum.

Sugiyono. 2017. Metode Penelitian Kombinasi (Mixed Methods). Bandung: Alfabeta

Undang-Undang No. 20 Tahun 2003 Tentang Sistem Pendidikan Nasional 